\section{Suicides without sadness}

\author{
Peter Tallack
}

Death by Design: Where Parallel Worlds Meet. A documentary film by Peter Friedman and Jean-François Brunet. Strange Attractions/Les Films du Bouc. 75 mins. To be broadcast in France and Germany on ARTE on 7 October, and later on public television in the United States and on RTBS in Belgium.

CELLS have finally made it onto celluloid. Death by Design is a highly original documentary about one particular aspect of their lives - their death. Made by Peter Friedman, an independent film maker, and Jean-François Brunet, a molecular neurobiologist, and sponsored by the CNRS, INSERM and the French Ministry of Research, the film truly lives up to its promise of making the screen "real and alive". Its "cast of billions" includes a vast array of unicellular organisms as well as slime moulds, nematode worms and other such multicellular notables as Polly Matzinger, Robert Horvitz, Rita Levi-Montalcini and Martin Raff. The combination of stunning images and informed commentary provides a perfect introduction to cell biology.

All the familiar topics are here, from the Dutch merchant and self-taught scientist Anton van Leeuwenhoek, one of the first people to see bacteria and protozoa, through to the spectacular diversity of cells, and on to the origin of multicellular organisms. (Incidentally, Van Leeuwenhoek, who nearly blinded himself by looking at gunpowder exploding under a microscope, was in fact born in 1632, a century later than Matzinger claims.)

But the film's main purpose is to expose one of the more elusive qualities of cells: programmed cell death, or 'apoptosis'. The process may be as important as cell division in generating an individual with the right number of different cell types in the right places. And because it is quick and covers its tracks, the deaths easily go unnoticed - as indeed they did during the decades when research on cell division flourished. It can regulate neuronal connections, dispose of cells that have finished their job and help to sculpt the shapes of developing organs. "Over and over again", says Raff, "biologists have learned that this is how biology works" - it produces thousands of variants and picks the few that succeed. To illustrate the point, the film cleverly switches to a shot of the cutting room, where the producer is seen editing the sequence just shown.

Microcinematography of cells is ingeniously meshed throughout the film with parallel images of life at the human scale. A screen seething with cells blends into scenes of the New York stock exchange; and images of dying cells collapsing in on themselves cut to imploding skyscrapers.
Rarely does the film fail to deliver something memorable, whether a startling fact (up to 90 per cent of neurons commit suicide in some regions of the developing human brain), or a neat turn of phrase ("the cells are not killed - they are told to

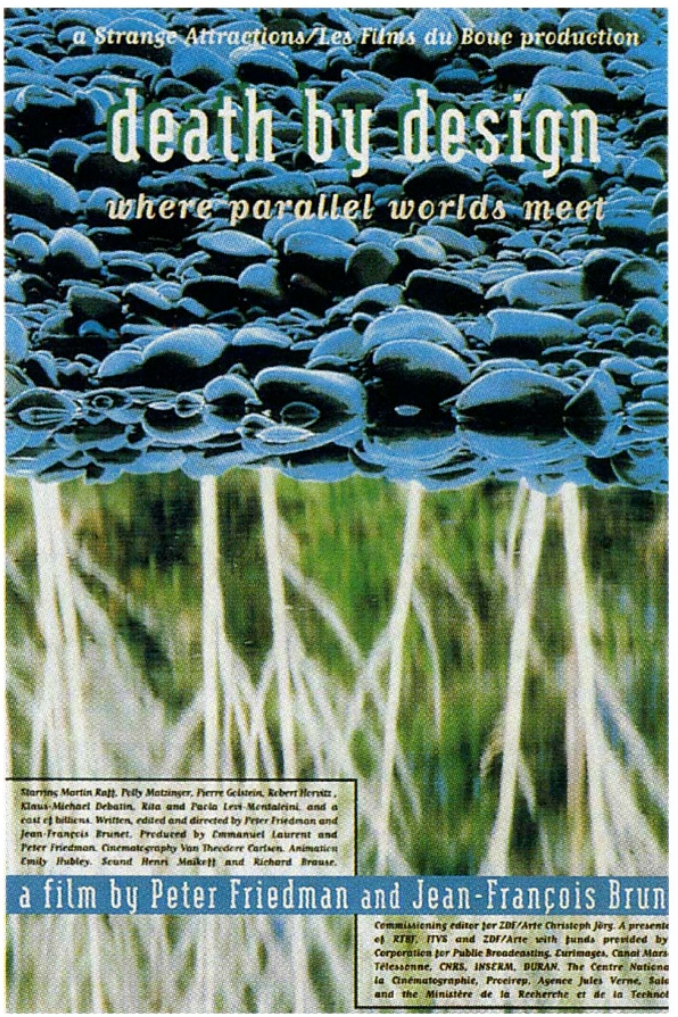

die", says Matzinger), or a piece of trivia (Horvitz, standing in his laboratory, estimates that he has between a billion and a trillion nematodes in the room with him), or a slapstick sequence (Harold Lloyd, the American daredevil comedian, is seen vainly trying to kill himself), or an unfamiliar image (a hundred lighted violins).

The biological dances of the living world are here portrayed as art: Sibelius accompanies a wonderful sequence of nematodes going about their business; bacteria mate to the rhythms of Bartok; and tadpoles metamorphose to the strains of a sitar raga. Great care has been lavished on presentation: some items are only a few seconds long, but are spliced with others to form a whole that, like an organism itself, transcends the sum of its parts.

There are moments of anthropomorphic excess, particularly the animated cartoon about the elimination of undesirable lymphocytes. But the philosophical limitation of seeing cells as people is unlikely to concern the general viewer, especially when it adds humour and charm to a tricky topic. One recurring analogy to which the film perhaps gives too much credence, however, is the idea that human society is a superorganism. To be sure, cells in an organism are clones of one another, and so may commit suicide in the genetic interests of the group as a whole. But it is doubtful whether people in a city kill themselves to promote the interests of a societal superorganism. And, as is pointed out, a cell can really be said to commit suicide only in the sense that it participates in its own death; it doesn't actually decide to die.

The film is by no means all about cells. There is also some delightful commentary on the nature of science. Why, for example, has something so fundamental as apoptosis been ignored for so long? Perhaps, it is suggested, it is because we had difficulty in seeing that the integrity of the living whole could depend on the death of many of its components. Or perhaps it is simply because in Western societies the idea of death - even that of a cell - is repulsive, reminding us of our own mortality.

Rita Levi-Montalcini, winner of the Nobel prize for medicine in 1986, agrees that our concept of death at the cellular level has completely changed. "We used to look at death as only negative", she says. "Today we also see it as positive." She vividly recounts how she set up a laboratory in her bedroom in Turin following the purge of Jews from Italian universities in 1938. Studying chick embryos, she provided the first demonstration that nerve cells die if a certain signal - nerve growth factor - is removed. "It was wartime, with its battlefields and death", she says. "These cells died, like soldiers at war. To me it looked like real life."

"In me", she goes on to say, "intuition prevails over reason - it is what science and art have in common." Raff also talks about the relationship between the two cultures, lamenting the British disdain for science, particularly among politicians. "Not only do they not know about science", he says, "but they do not want to know about science - they would consider it demeaning, somehow polluting their ethereal spirit. Isn't it depressing? It is depressing."

Thankfully, there can be few happier marriages between the two cultures of scientific enquiry and the humanities than this enthralling documentary. It stimulates both curiosity and imagination; illuminates the world of cells with great charm and unpretentious artistry; and explains its biological wonders with poetic clarity. Leeuwenhoek would have been dying to see it.

Peter Tallack is Book Review Editor of Nature. 